\title{
Clinical Immunologic Interventions for the Treatment of Type 1 Diabetes
}

\author{
Lucienne Chatenoud ${ }^{1}$, Katharina Warncke ${ }^{2,3}$, and Anette-G. Ziegler ${ }^{3,4}$ \\ ${ }^{1}$ Université Paris Descartes, INSERM, Unité 1013, Hôpital Necker Enfants Malades, Paris, France \\ ${ }^{2}$ Department of Pediatrics, Klinikum Rechts der Isar, University of Technology, Munich, Germany \\ ${ }^{3}$ Institute of Diabetes Research, Helmholtz Center Munich, German Research Center for Environmental \\ Health, Germany \\ ${ }^{4}$ Forschergruppe Diabetes, Klinikum Rechts der Isar, University of Technology, Munich, Germany \\ Correspondence: lucienne.chatenoud@inserm.fr; anette-g.ziegler@helmholtz-muenchen.de
}

Type 1 diabetes is an autoimmune disease, hence the rationale for immunotherapy to halt disease progression. Based on knowledge gained from other autoimmune diseases and from transplantation, the first immunointervention trials used immunosuppressive drugs, e.g., cyclosporin, in patients with recently diagnosed type 1 diabetes. Although remarkable, the effect vanished following drug withdrawal. Efforts were then devoted to devise strategies to induce/restore self-tolerance and avoid chronic immunosuppression. Various approaches were identified from work in spontaneous models of autoimmune diabetes, including the use of $\beta$-cell autoantigens and monoclonal antibodies directed at relevant immune molecules such as costimulatory ligands, T-cell receptor molecules such as CD3, and B cells. Phase II and phase III trials were launched, results of which are now available. Although the endeavor is challenging, the experience gained indicates that immunotherapy appears as the real hope of inducing long-term remission of the disease provided the treatment is started early and that protocols are adapted based on lessons from the past.

$\mathrm{C}$ onverging evidence from animal models and clinical trials have shown that a key component of the pathogenesis of type 1 diabetes (T1D) is the autoimmune reaction to $\beta$-cell autoantigens and the associated inflammation. Although a triggering role of certain environmental factors (e.g., viruses) and a genetically determined susceptibility of $\beta$ cells to such factors must not be disregarded, the commencement and extent of the subsequent $\beta$-cell destruction are owing to interplay between the innate and adaptive immune systems. This concept forms the basis for efforts to counter the immune attack so as to durably stop T1D progression as chronic administration of insulin is only a substitutive treatment. Importantly, current epidemiological studies predict a dramatic impact of T1D on public health in the near future. The disease incidence will continue to significantly increase in the coming decade and the pathology will proportionally affect predominantly very young children under 5 years

Editors: Jeffrey A. Bluestone, Mark A. Atkinson, and Peter Arvan

Additional Perspectives on Type 1 Diabetes available at www.perspectivesinmedicine.org

Copyright (C) 2012 Cold Spring Harbor Laboratory Press; all rights reserved; doi: 10.1101/cshperspect.a007716

Cite this article as Cold Spring Harb Perspect Med 2012;2:a007716 


\section{Chatenoud et al.}

of age (Patterson et al. 2009). Any T1D immunotherapeutic approach must build on known approaches for manipulating autoimmune mechanisms to devise novel therapeutic strategies that address this ballooning unmet medical need. In the context of the young patient population increasingly affected by T1D, the challenge is to obtain clinical efficacy in the absence of chronic immunosuppression without com- promising the host's defense against infections and tumors. This provides the rationale to reestablish immune tolerance to $\beta$-cell autoantigens (Fig. 1). Seminal experiments in the late 1950s, by Billingham, Brent, and Medawar established that immune tolerance was not innate and could be induced on introduction of the target antigen (defined as the "tolerogen"), in a host harboring an immature immune system, namely, newborns
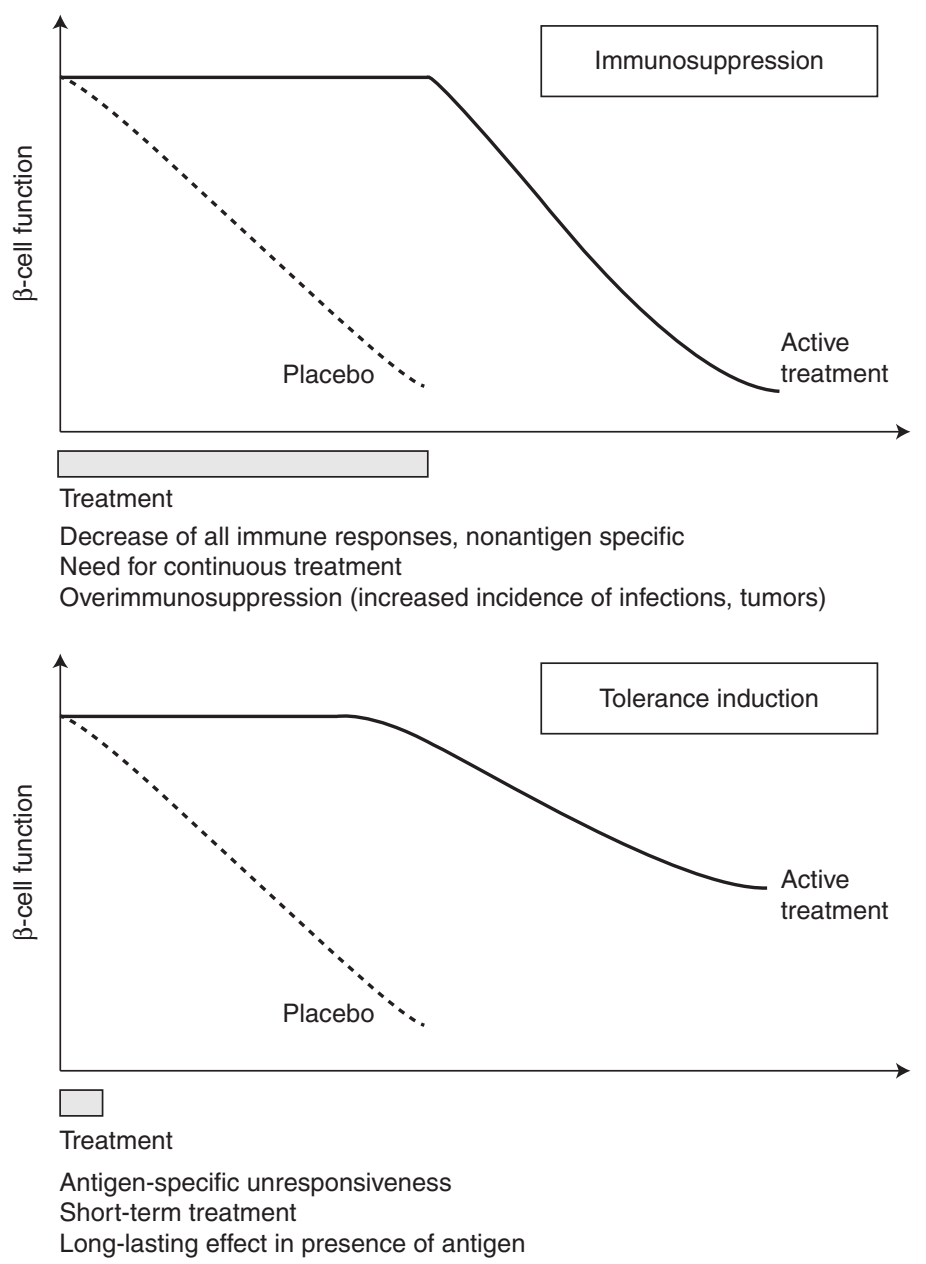

Figure 1. Schematic representation of an immunosuppressive versus an immune tolerance-inducing strategy. The figure addresses the type of clinical result, in terms of preservation of $\beta$-cell mass, one may expect from a therapeutic strategy involving an immunosuppressive agent (upper panel) versus one inducing immune tolerance (lower panel). The therapeutic effect of the immunosuppressive agent will be observed only during the time of treatment and will vanish on drug withdrawal. In the case of lymphocyte depleting agents (such as the CD20 antibody Rituximab) the effect will reverse when cell reconstitution occurs. At variance, with agents that induce operational tolerance the therapeutic effect will last long after the end of treatment in the absence of chronic immunosuppression. 
(Billingham et al. 1953). These first experiments used allogeneic cells as the tolerogen injected once into neonates that as adults tolerated the cells indefinitely, in the absence of any immunosuppressive treatment. Moreover, recipients were able to tolerate skin grafts from the same donors of the cells injected at birth, whereas third-party grafts were readily rejected. In the following decade, evidence was accumulated to show that these data could be extended to adult hosts provided the tolerogen was introduced under the cover of a short treatment with an adequate immunomodulating drug. A major effect of these treatments was to increase the number and/or the functional capacity of specialized subsets of T lymphocytes (i.e., regulatory T cells) that actively control the pathogenic effectors.

In practice, therapies such as CTLA4-Ig (Abatacept) (Orban et al. 2011) that block costimulation, or CD20 monoclonal antibody ( Rituximab) that reduce B-cell contribution to autoimmunity (Pescovitz et al. 2009) have resulted in significant improvement of $\beta$-cell function, at least short term. Pilot trials with anti-inflammatory drugs have shown similar promising effects (anti-TNF, IL-1Ra ...). Vaccination with autoantigen has been shown to alter antigen-specific immunity and initial studies reported some preservation of $\beta$-cell function (Ludvigsson et al. 2008). However, these observations were not confirmed in more recently reported phase II and III studies (Wherrett et al. 2011). Strategies using short treatment ( $1-2 \mathrm{wk}$ ) with monoclonal antibodies to CD3 that interfere with pathogenic T-cell activation provided encouraging results in both academic phase II trials (Herold et al. 2002, 2005; Keymeulen et al. 2005, 2010) and in a recently reported phase III study (Sherry et al. 2011). Efficacy, as assessed by maintenance of $\beta$-cell function and decrease in insulin needs was observed, depending on the study, for 1-4 yr after the end of treatment. Finally, more aggressive treatment with lymphoablation followed by autologous hematopoietic stem cell transplantation appears particularly effective with reports of medium-term T1D reversal (Voltarelli et al. 2007; Couri et al. 2009).

Transferring these promising therapies into pharmaceutical products with consistent effica- cy or therapies where efficacy outweighs risk remains an obstacle as seen in recent follow-up trials. Nevertheless, the field is currently both relatively rich in immune intervention possibilities and ready to test sensible therapeutic combinations. Ultimately, it is hoped that the efforts will result in a range of immune therapy options that combine short-term $\beta$-cell preservation treatments with long-term modulation of autoimmunity. As in other immune-mediated diseases, one treatment is unlikely to be effective in all patients.

We will need to have markers of clinical and immune efficacy, together with identifying combination treatments that can guide immune therapy for individual patients. This article provides an overview of the type of immune intervention that has been used in T1D patients, along with specific successes and failures and hopes to draw inferences that may help future attempts to develop immune therapy for T1D. It is important to mention that we did not aim at raising an exhaustive list of all the trials that have been conducted in the past. We focused on clinical studies that we believe represent important landmarks for future development (Table 1). Thus, studies such as the nicotinamide or casein diet are not included. In addition, we concentrated on ongoing strategies that have reached the stage of phase II or phase III trials. Thus, novel immunointervention avenues using biological agents (i.e., LFA3 fusion protein) or cell therapy approaches (i.e., regulatory T-cell [Treg] based cell therapy) are not discussed.

\section{IMMUNOSUPPRESSION}

Because T1D has an autoimmune component as evidenced by the presence of islet-cell autoantibodies and memory autoreactive $\mathrm{T}$ cells before diabetes onset, suppressing immune response through the use of immunosuppressive drugs was tested in the 1980s and even recently. Some of these attempts were successful in inducing and prolonging clinical remission. However, effects were lost on drug withdrawal because they were nonantigen specific, did not lead to immune tolerance, and were sometimes associated with side effects that prevented their broad use. 


\section{Chatenoud et al.}

Table 1. Immunotherapy strategies applied in clinical autoimmune type 1 diabetes

\begin{tabular}{|c|c|c|c|c|}
\hline Strategy & Treatment & Indication & $\begin{array}{l}\text { Target immune } \\
\text { cell/mediator }\end{array}$ & Mode of action \\
\hline \multirow[t]{6}{*}{ Immunosuppression } & Cyclosporin A & Established T1D & $\mathrm{T}$ cells & $\begin{array}{l}\text { Inhibition of cytokine } \\
\text { production }\end{array}$ \\
\hline & $\begin{array}{l}\text { Mycophenolate and } \\
\text { Daclizumab }\end{array}$ & Established T1D & $\begin{array}{l}\text { MMF : } \\
\text { Lymphocytes }\end{array}$ & $\begin{array}{l}\text { MMF: Inhibition of cell } \\
\text { proliferation }\end{array}$ \\
\hline & $(\mathrm{CD} 25 \mathrm{moAb})$ & & $\begin{array}{l}\text { CD25 moAb: } \\
\text { CD25 }{ }^{+} \text {T cells }\end{array}$ & $\begin{array}{l}\text { CD25 moAb: Targeting of } \\
\text { CD2 } 25^{+}\end{array}$ \\
\hline & Rituximab & Established T1D & $\mathrm{B}$ cells $\left(\mathrm{CD} 20^{+}\right)$ & $\begin{array}{l}\text { B-cell depletion (Pescovitz } \\
\text { 2009) }\end{array}$ \\
\hline & CTLA4-Ig & Established T1D & $\begin{array}{r}\text { Interaction } \mathrm{T} \\
\text { cells } / \mathrm{APCs}\end{array}$ & $\begin{array}{l}\text { Inhibition effector T-cell } \\
\text { activation (Bluestone } \\
\text { et al. 2006) }\end{array}$ \\
\hline & Vitamin D3 & Established T1D & APCs & $\begin{array}{l}\text { APCs acquire an anti- } \\
\text { inflammatory } \\
\text { phenotype (Penna et al. } \\
\text { 2007a,b) }\end{array}$ \\
\hline \multirow[t]{3}{*}{ Anti-inflammatory } & Anti-TNF $\alpha$ & Established T1D & $\mathrm{TNF} \alpha$ & \multirow{3}{*}{$\begin{array}{l}\text { Prevention of cytokine- } \\
\text { mediated } \beta \text {-cell } \\
\text { aggression (Eizirik 2009; } \\
\text { Mandrup-Poulsen 2010) }\end{array}$} \\
\hline & Anti-IL- $1 \alpha$ & Established T1D & IL- $1 \alpha$ & \\
\hline & Anti-IL-1 $\beta$ & Established T1D & IL-1 $\beta$ & \\
\hline \multirow[t]{8}{*}{$\begin{array}{l}\text { Restoration of } \\
\text { self-tolerance }\end{array}$} & CD3 antibodies & Established T1D & $\mathrm{T}$ cells $\left(\mathrm{CD} 3^{+}\right)$ & $\begin{array}{l}\text { Depletion of activated } \\
\text { CD } 3^{+} \text {cells: Induction of } \\
\text { CD } 4^{+} \text {CD } 25^{+} \text {Tregs } \\
\text { (Chatenoud and } \\
\text { Bluestone } 2007 ; \\
\text { Chatenoud } 2010)\end{array}$ \\
\hline & Autoantigens & & & \\
\hline & $\begin{array}{l}\text { Subcutaneous } \\
\text { insulin }\end{array}$ & Prediabetes & \multirow{7}{*}{$\begin{array}{l}\text { APCs } \\
\text { Autoreactive } \\
\quad \mathrm{T} \text { cells }\end{array}$} & \multirow{7}{*}{$\begin{array}{l}\text { Induction of immune } \\
\text { regulation } \\
\text { Immune deviation (Th1 to } \\
\text { Th2) (Tian et al. 1996; } \\
\text { Elias et al. 1997; Tisch } \\
\text { et al. 1999; Ludvigsson } \\
\text { et al. 2008) }\end{array}$} \\
\hline & Insulin APL & Established T1D & & \\
\hline & Oral insulin & Established T1D & & \\
\hline & & Prediabetes & & \\
\hline & Intranasal insulin & Prediabetes & & \\
\hline & GAD Alum & Established T1D & & \\
\hline Hsp60 peptide & Established T1D & & & \\
\hline
\end{tabular}

Abbreviations: T1D, type 1 diabetes; MMF, mycophenolate mofetil; APCs, antigen-presenting cells; TNF, tumor necrosis factor; APL, altered-peptide ligand; GAD, glutamic acid decarboxylase.

\section{Cyclosporin A}

One of the earliest drugs used for immunosuppression in patients with newly diagnosed T1D was cyclosporin A (CSA). CSA is an 11-amino acid cyclic peptide of fungal origin with strong immunosuppressive capacity. It is a calcineurin inhibitor that interferes with $\mathrm{T}$-cell receptor (TCR)-mediated signal transduction, thus inhibiting T-cell activation, and the production of interleukin (IL)-2 by helper T cells, and thereby limiting the amplification of immune responses (Sigal and Dumont 1992). In T1D, CSA provided the first proof of the concept that T-cell-directed immunosuppression was efficacious in prolonging $\beta$-cell function and insulin production.

Based on results from pilot studies (Stiller et al. 1984; Assan et al. 1985) two randomized phase II placebo-controlled studies were conducted, one in France and one in Canada and Europe (Feutren et al. 1986; The Canadian-European Randomized Control Trial Group 1988). 
The results of the French study, published in 1986, including 122 adolescents and adults (15-40 years) within 6 weeks after initiation of insulin therapy showed that CSA had a significant effect in decreasing insulin needs at nine months of a daily CSA treatment using a dose of $7.5 \mathrm{mg} / \mathrm{Kg}$ (Feutren et al. 1986). An increased proportion of patients treated with CSA as compared with placebo could be weaned off insulin treatment, and this was more pronounced in patients with therapeutically efficacious residual levels of CSA. Another factor influencing the response rate, was the initial value of $\mathrm{C}$-peptide measured on day 0 before starting treatment; the higher the initial C-peptide value the higher the proportion of responders. In the Canadian/European trial reported in 1988, 188 patients aged $10-35$ yr were included also within 6 weeks after initiation of insulin therapy and within 14 weeks after the beginning of symptoms. At 1 year, 24\% of the CSA group and 10\% of the placebo group were in complete remission weaned off insulin (The Canadian-European Randomized Control Trial Group 1988). After discontinuation of CSA after 13.8 months, metabolic control in the CSA group was transiently worse than in the placebo group, and interestingly, insulin antibodies and IgG1 subclasses that were suppressed during CSA treatment rebounded after termination of therapy (Füchtenbusch et al. 2000). In the two studies the investigators concluded that treatment with CSA had no long-lasting effect on the course of T1D persisting beyond drug administration (Feutren et al. 1986; Martin et al. 1991). The need for chronic drug administration, the potential renal and pancreatic $\beta$-cell toxicity, as well as the costs for the drug led to the consensus that the risks outweighed the benefits.

\section{Mycophenolate Mofetil}

Mycophenolate mofetil (MMF) is an immunosuppressive drug that has been used in the context of organ allograft rejection. MMF has potent cytostatic effects on lymphocytes (Brazelton and Morris 1996). After oral administration it is hydrolyzed to mycophenolic acid (MPA), which inhibits inosine monophosphate dehydrogenase, the enzyme that controls the rate of synthesis of guanine monophosphate in the de novo pathway of purine synthesis that is essential for the proliferation of $\mathrm{B}$ and $\mathrm{T}$ lymphocytes. However, despite its efficacy in organ transplantation, a combination of MMF and a monoclonal antibody (Daclizumab) specific for CD25, the $\alpha$ chain of the IL-2 receptor, which is widely used in transplantation (Vincenti et al. 1998) did not preserve $\beta$-cell function when used to treat newly diagnosed patients with T1D (Gottlieb et al. 2010). In addition, there was no decrease in insulin requirement or improvement in metabolic control. One-third of patients treated with the combination of Daclizumab and MMF suffered from serious adverse events. Although negative, this data is relevant as it highlights that it is not any immunosuppressive regimen that can effectively treat T1D. One reason to explain the failure is that by targeting $\mathrm{CD} 4{ }^{+} \mathrm{CD} 25^{+}$regulatory $\mathrm{T}$ cells (Tregs), Daclizumab removes from the immune system a cell subset shown to play an essential role in the maintenance of self-tolerance in T1D (Salomon et al 2000; Sakaguchi et al 2006).

\section{Rituximab}

It has been well established that $\mathrm{CD} 4^{+}$and $\mathrm{CD} 8^{+}$ $\mathrm{T}$ cells are the pathogenic effectors mediating the destruction of insulin-secreting $\beta$ cells. The antibodies to various $\beta$-cell antigens (insulin, glutamic acid decarboxylase [GAD], IA-2, and ZnT8) that are produced by autoreactive B cells and are detected in diabetic patients and prediabetic "at-risk" individuals are nonpathogenic. They represent, however, very good markers of $\beta$-cell destruction and disease progression. It was therefore a surprise when data were published showing that B cells played a major role in the development of T1D. Indeed, elimination of $B$ cells by disrupting the gene encoding the $\mu$ immunoglobulin chain in nonobese diabetic (NOD) mice led to complete protection from disease (Serreze et al. 1996). More recently, compelling evidence has accumulated demonstrating that B lymphocytes play a pivotal role as autoantigen-presenting cells leading to parallel studies of CD20 antibodies in the NOD mouse and early-onset patients with T1D. Transgenic 
L. Chatenoud et al.

NOD mice expressing the human CD20 on B cells were used owing to lack of available antimouse CD20 antibodies (Hu et al. 2007). Treatment of these mice with a single cycle of an antihuman CD20 monoclonal antibody, which temporarily depleted B cells, significantly reduced and delayed the onset of diabetes. Furthermore, diabetes could be reversed in about onethird of overtly diabetic mice (Hu et al. 2007).

In the clinic the antibody used is the chimeric humanized monoclonal antibody Rituximab, which selectively depletes B lymphocytes and which was initially established for the treatment of lymphoma (Reff et al. 1994; Pescovitz et al. 2009). In T1D, Rituximab showed a significant effect on $\beta$-cell function at 1 yr after randomization when administered on days 1, 8, 15, and 22 of the study (Pescovitz et al. 2009). The level of C-peptide was significantly higher in the Rituximab group compared with the placebo group. The Rituximab group also had significantly lower HbA1c levels and required less insulin. Unfortunately, the effect was not longlasting as immune tolerance was not induced. Moreover, immunological monitoring studies showed a significant yet reversible incapacity of treated patients to mount efficient antibody responses for several months after treatment, linked to the deep and prolonged B-cell depletion observed. However, this trial was considered important by pointing to the need to learn more about how to combine treatments intervening with both $\mathrm{T}$ - and $\mathrm{B}$-cell function.

\section{CTLA4-Ig}

Abatacept is a fusion protein composed of an Fc portion of an immunoglobulin fused to the extracellular domain of CTLA4, a T-cell-negative costimulation receptor. Abatacept contains a high-affinity binding site for CD80 and CD86 and works by binding to these ligands on antigen-presenting cells and preventing them from delivering CD28-mediated costimulatory signals to $T$ cells, thus preventing their full activation. CTLA4-Ig, termed Abatacept, was first approved for the treatment of rheumatoid arthritis (Kremer et al. 2003). Subsequently, a mutant form LEA29Y, or belatacept, with two amino acid mutations in the extracellular domain that bound CD80 twofold better and CD86 fourfold better than Abatacept, was validated and approved in transplantation as part of the immunosuppression maintenance regimens to avoid the use of calcineurin inhibitors CSA and FK506 (Vincenti et al. 2005; Bluestone et al. 2006; Wojciechowski and Vincenti 2011).

Abatacept was tested in a multicenter, double-blind, randomized controlled trial, including patients aged 6-45 yr recently diagnosed with T1D. Patients received Abatacept (10 mg/ $\mathrm{kg}$, maximum $1000 \mathrm{mg}$ per dose) or placebo intravenously on days 1,14 , and 28 , and then monthly for a total of 27 infusions over 2 years (Orban et al. 2011). The difference between groups was present throughout the trial, with an estimated delay in C-peptide reduction with Abatacept of about 10 months. A decrease in insulin needs was also reported, which, however, was noted only for the first 12 months of treatment (Orban et al. 2011). A longer follow-up is needed to assess if, and if yes, for how long the effect is maintained after treatment cessation. Indeed, some studies in mouse models have raised questions about the effects of CTLA4Ig in promoting immune tolerance and a longlasting therapeutic effect if administered alone. First, Tregs are dependent on CD28 for their thymic development and their survival at the periphery (Salomon et al. 2000; Tang et al. 2003). As a consequence, complete blockade of CD80 and CD86 with CTLA4-Ig drastically reduced Tregs and exacerbated autoimmunity (Tang et al. 2003). Second, it has been well established that CD28-B7 interactions are more relevant for the stimulation of naïve than for memory $\mathrm{T}$ cells (Bluestone et al. 2006), raising the question as to the real effectiveness of CTLA4-Ig in advanced stages of T1D as we are discussing here.

\section{Vitamin D3}

$1,25(\mathrm{OH})_{2} \mathrm{D} 3$ was introduced to the clinic as a therapy to increase intestinal calcium resorption and serum levels of calcium, e.g., in patients with renal insufficiency. Epidemiological and experimental data suggested that $1,25(\mathrm{OH})_{2} \mathrm{D} 3$ could be of benefit in the treatment of T1D. 
A Finnish multinational case-control study and a birth cohort follow-up study with prerecorded exposure data (VIT D Eurodiab 1999; Hypponen et al. 2001) suggested that vitamin D3 supplementation at birth, protected individuals from T1D development. A meta-analysis also argued in favor of such conclusion ( $\mathrm{Zi}$ pitis and Akobeng 2008). Some investigators reported data on lower serum levels of 1,25-dihydroxyvitamin D3 $\left[1,25(\mathrm{OH})_{2} \mathrm{D} 3\right.$, calcitriol] in patients with recently diagnosed T1D as compared with healthy controls (Baumgartl et al. 1991), which, however, were not confirmed by others (Bierschenk et al. 2009).

Treatment of NOD mice with $1,25(\mathrm{OH})_{2} \mathrm{D} 3$ reduces the incidence of insulitis and diabetes but only if applied at an early disease stage and not at the time of overt hyperglycemia (Gysemans et al. 2005; Mathieu et al. 2005). Furthermore, a series of mechanistic studies have reproducibly shown that $1,25(\mathrm{OH})_{2} \mathrm{D} 3$ affects both innate and adaptive immunity by modulating dendritic cell maturation in vitro and in vivo (Penna et al. 2007a,b).

Transfer of the strategy to the clinic was disappointing. A first report of a pilot open study in which patients received intensive insulin therapy and either $0.25 \mu \mathrm{g}$ calcitriol on alternate days or nicotinamide with up to 1-year followup showed no difference in C-peptide preservation and a modest and transient reduction in insulin needs in the group receiving calcitriol (Pitocco et al. 2006). A subsequent phase II trial aimed at using higher doses of $1,25(\mathrm{OH})_{2} \mathrm{D} 3$ to determine whether these were safe and could prevent loss of $\beta$-cell function when applied to patients with recent-onset T1D. Forty patients were randomly assigned to receive $0.25 \mu \mathrm{g}$ of $1,25(\mathrm{OH})_{2} \mathrm{D} 3$ or placebo daily for 9 months. At 18 months of follow-up no significant differences in $\beta$-cell function were observed (Walter et al. 2010).

\section{ANTI-INFLAMMATORY}

Inflammation at the islet is very likely a concomitant pathogenic occurrence at T1D onset, and may also be involved earlier in the disease process (Eizirik et al. 2009). Cytokines function as proinflammatory signals and mediate acute phase responses in infection and inflammation. Moreover, innate immune responses are often activated by cell destruction. Blocking inflammation by anti-inflammatory agents has been used with good effect in several autoimmune diseases such as rheumatoid arthritis, psoriasis, and juvenile rheumatoid arthritis (Ogilvie et al. 2001; Feldmann 2002), and is also tested in T1D.

\section{Blockade of TNF $\alpha$}

Etanercept is a recombinant soluble tumor necrosis factor (TNF) $\alpha$ receptor fusion protein that binds to TNF $\alpha$ thereby blocking its activity. A pilot study has been performed in children with new-onset T1D (Mastrandrea et al. 2009). In a double-blind placebo-controlled trial patients were treated with either Etanercept or placebo twice a week. Eighteen patients aged 7-18 yr were included. From baseline to 24 weeks the change in $\mathrm{C}$-peptide area under the curve showed a 39\% increase in the treated group compared with a $20 \%$ decrease in the placebo group. This was associated with a corresponding decrease of insulin dose (18\%) in the Etanercept group but an increase of insulin dose $(23 \%)$ in the placebo group. There were no serious adverse events; only a slight increase of mild to moderate adverse events in the Etanercept group was observed. In summary, this pilot trial is encouraging but larger trials are needed.

\section{IL-1-Antagonists}

Interleukin 1 (Il-1) is selectively cytotoxic to rodent and human $\beta$ cells in vitro, and anti-IL-1 therapies reduce diabetes incidence in animal models of diabetes (Mandrup-Poulsen 1996).

Anakinra: In a randomized trial (Larsen et al. 2007), 70 patients with type 2 diabetes (T2D) were treated with $100 \mathrm{mg}$ anakinra once daily or placebo for 13 weeks. The results showed an improvement of metabolic control (HbAlc, C-peptide, and proinsulin-to-insulin ratio) in the anakinra compared with the placebo group. The results suggested that long-term inhibition of IL- 1 action may preserve $\beta$-cell function in T2D as well as in T1D. Anakinra is 
L. Chatenoud et al.

a recombinant, nonglycosylated form of the human IL-1Ra. It differs from native human IL$1 \mathrm{Ra}$ in that it has the addition of a single methionine residue to its amino terminus. Anakinra blocks the biologic activity of IL-1 by competitively inhibiting IL-1 binding to the IL-1 type I receptor, which is expressed in a wide variety of tissues and organs (Hannum et al. 1990). The anti-interleukin-1 in diabetes action (AIDA) study tests the feasibility, safety, and efficacy of anti-IL-1 therapy in maintaining/enhancing $\beta$ cell function in people with new-onset T1D (Mandrup-Poulsen et al. 2010). Patients are instructed to administer anti-IL-1 therapy in the form of anakinra at a dose of $100 \mathrm{mg}$ once daily or placebo by subcutaneous injection. Recruitment is ongoing.

Canakinumab (anti-interleukin-1 $\beta$ ): Another ongoing trial tests whether repeated injections of canakinumab will preserve $\beta$-cell function in newly diagnosed patients with T1D. Canakinumab is a fully human anti-interleukin-1 $\beta$ (anti-IL-1 $\beta$ ) monoclonal antibody (IgG-1 class). Canakinumab is designed to bind to human IL-1 $\beta$ and to functionally neutralize the bioactivity of this proinflammatory cytokine. Sixty-six subjects will be assigned to receive either monthly subcutaneous injections of $2.0 \mathrm{mg} / \mathrm{kg}$ canakinumab, or placebo for 12 months (http://clinicaltrials.gov/ct2/ show/NCT00947427).

\section{"REPROGRAMMING" THE IMMUNE SYSTEM TO INDUCE IMMUNE TOLERANCE}

As discussed above, the various clinical trials conducted using immunosuppressive treatments have had the great merit of showing that it is possible to halt the progression of T1D once hyperglycemia is recently established, a point in time where about $30 \%$ of the $\beta$-cell mass is still present yet not functional owing to the ongoing islet infiltration and inflammation (Sreenan et al. 1999). However, the global depression of immune responses induced by immunosuppression, and the requisite chronic drug administration has potential side effects that are unacceptable given that the particular target population includes mostly children and young adults (Chatenoud 2010; Bach and Chatenoud 2011). Thus, despite their objective effectiveness, none of these strategies are considered for a wide application in T1D unless they can be combined with other therapies leading to elimination of the need for chronic drug therapy. Indeed, today the objective of immune therapy in T1D is more stringent, the aim being to show that efficacy could translate into benefit to the patient without major risks. In this context, the only solution is to induce/restore immune tolerance to $\beta$-cell autoantigens, which, irrespective of the underlying mechanisms, is the harnessing of the pathologic immune response in the absence of chronic immunosuppression. We will focus on two strategies that in experimental studies have proved promising and have led to significant clinical efforts. These biologics possess the ability to "reprogram" the immune system toward tolerance without necessitating the exogenous administration of the autoantigen(s) and the use of candidate autoantigens. For the sake of completeness we shall also discuss the more limited, yet interesting, attempts to translate to T1D an approach previously applied in other autoimmune diseases, which is autologous bone marrow transplantation.

\section{Polyclonal Antilymphocyte Globulins}

As mentioned previously, immune tolerance is not innate and may be induced in adult hosts following encounters with the target antigen under the cover of an adequate short immunomodulatory treatment. The first such treatment described was polyclonal rabbit antilymphocyte serum (ALS), also termed polyclonal antilymphocyte globulin (ALG) (or antithymocyte globulin [ATG] when thymocytes were used for the immunization instead of lymphocytes). ALS/ALG and ATG are in fact a mixture of immunoglobulins directed at various $\mathrm{T}$ and B lymphocyte receptors. Immune tolerance to fully mismatched tissue grafts was successfully induced using ALS/ALG both in rodents and even in nonhuman primates (Monaco et al. 1966; Wood et al. 1971). The works by Like and Rossini and Maki et al. showed that this remarkable tolerance-inducing capacity of ALS could 
be applied to the BioBreeding (BB) rat and the nonobese diabetic (NOD) mice showing recently established hyperglycemia (Like et al. 1979; Maki et al. 1992). Only two injections of ALS restored a normal metabolic control in $76 \%$ of mice owing to restoration of self-tolerance, which lasted throughout the life of the mice. ALS and ATG induce substantial T-cell depletion that lasts for several weeks after the end of treatment. Interestingly, mechanistic studies performed in NOD mice showed that following T-cell reconstitution there was an increase in the frequency and the functional capacity of $\mathrm{CD} 4{ }^{+} \mathrm{CD} 25^{+}$regulatory T cells (Tregs) (Simon et al. 2008).

In the clinic, antilymphocyte sera are used mostly as immunosuppressants in organ and bone marrow transplantation, although there is one additional indication, acquired aplastic anemia. In this setting, ALS treatment can reverse this severe autoimmune disease where hematopoietic progenitor and stem cells are targeted by immune effector T cells and cytokines (Young et al. 2006). In the 1970s, the observation of autologous marrow reconstitution in patients with rejected bone marrow grafts suggested that the conditioning agents used for transplantation, such as ALS, might be therapeutic. Use of rabbit ALS and ATG as well as ATG made in horses (ATGAM) became an established therapy for this disease.

In T1D a first small trial was conducted in 1985 by Eisenbarth et al. using ATGAM and prednisone. Clinical effectiveness was observed, which was, however, outweighed by the side effects observed (i.e., thrombocytopenia) (Eisenbarth et al. 1985). Another study in 2004 reported on 11 patients who received rabbit ATG and were followed for 1 year. Clinical remission was observed in treated patients (two patients reached insulin independency) (Saudek et al. 2004). Side effects were transient fever and moderate symptoms of serum sickness (Saudek et al. 2004). The START trial (study of thymoglobulin to arrest type 1 diabetes), headed by S. Gitelman at UCSF in partnership with the Immune Tolerance Network is including patients with recent-onset T1D aged $12-35$ yr to test the capacity of ATG to halt disease progression.

\section{CD3 Monoclonal Antibodies}

As mentioned above, antilymphocyte sera are in fact a mixture of immunoglobulins directed at various $\mathrm{T}$ and $\mathrm{B}$ lymphocyte receptors. It thus appeared logical that monoclonal antibodies to individual functionally relevant immune cell receptors, could advantageously replace polyclonal preparations, which are laborious to produce and standardize and elicit side effects linked to their polyclonal nature, such as serum sickness. With respect to T1D, the most convincing data were obtained with monoclonal antibodies to CD3 and CD4, which were the only specificities to fully reproduce the effect observed with ALS, namely, long-standing disease remission following a short treatment (Maki et al. 1992; Chatenoud et al. 1994; Makhlouf et al. 2004). For CD4 antibodies, the effect was observed with depleting CD4 antibodies but not with nondepleting ones (Maki et al. 1992). At variance, CD3 antibodies were effective despite the partial and very transient depletion they induce, especially when Fc receptor nonbinding CD3 antibodies are used (i.e., in the mouse $F\left[\mathrm{ab}^{\prime}\right] 2$ fragments or IgG3 CD3 antibodies, and in patients, humanized Fc-mutated CD3 antibodies) (Hirsch et al. 1990; Chatenoud et al. 1994; Chatenoud and Bluestone 2007).

As previously mentioned for ALS, one interesting feature of CD3 antibodies is that they afford treatment of ongoing disease and restoration of self-tolerance without the need for exogenous administration of $\beta$-cell autoantigen(s). It has been well established that the presence of the tolerogen is needed for antiT-cell antibodies to promote their antigen-specific therapeutic effect, a requirement, which is met in the case of T1D because $~ 30 \%$ of the $\beta$-cell mass is still present at onset of hyperglycemia (Sreenan et al. 1999). Another important characteristic of CD3 antibodies is that they act on both pathogenic $\mathrm{T}$ and Tregs (Chatenoud 2010; Penaranda et al. 2011). The unique effect on locally activated autoreactive $\mathrm{T}$ cells explains that CD3 antibodies are mainly effective in the context of a primed and ongoing immune response (an effect observed both in NOD mice and in experimental allergic 


\section{Chatenoud et al.}

encephalomyelitis [EAE]) (Chatenoud et al. 1997; Chatenoud 2003; Kohm et al. 2005; Chatenoud and Bluestone 2007). The effect on $\mathrm{CD} 4{ }^{+} \mathrm{CD} 25^{+} \mathrm{FoxP}^{+}$Tregs, which regain their functional capacity to suppress and are TGF- $\beta$ dependent (Belghith et al. 2003; You et al. 2006, 2007), correlates with the recurrence of a noninvasive/destructing insulitis (Chatenoud et al. 1994, 1997).

The results obtained in NOD mice encouraged the initiation of clinical trials in humans using protocols very similar to those described in mice ( $1-2 \mathrm{wk}$ treatment). This was facilitated by the availability of humanized CD3 monoclonal antibodies mutated in their Fc fragment to limit the cross-linking of Fc receptors expressing cells ( phagocytes, natural killer [NK] cells), thereby significantly decreasing their T-cell activating and cytokine release capacities (e.g., a real problem leading to severe side effects following treatment with murine CD3 antibodies such as OKT3) (Chatenoud and Bluestone 2007). The results obtained in two phase II trials, one of which was placebo controlled, were impressive (Herold et al. 2002, 2005; Keymeulen et al. 2005, 2010). Patients who received CD3 antibodies showed a sustained remission of the disease, up to 4 years for the aglycosylated antibody otelixizumab (Keymeulen et al. 2010). As in trials using CSA, responses were best in patients presenting with higher functional $\beta$-cell mass before starting otelixizumab treatment: $75 \%$ of patients in this subgroup were clinically insulin independent (i.e., insulin needs were $\leq 0.25$ units $/ \mathrm{Kg} / \mathrm{d}$ ) at 18 months posttreatment contrasting with none in the placebo group (Keymeulen et al. 2005).

Based on these results, phase III trials were launched by two biotech companies in association with large pharmaceutical companies, using designs that were quite different from those of the previous phase II studies. The phase III study using teplizumab (MacroGenics/Eli Lilly trial) had a composite end point chosen arbitrarily (i.e., insulin requirement $\leq 0.5$ units/ $\mathrm{Kg} / \mathrm{d}$ and HbAlc $\leq 6.5 \%)$ that had not been previously validated in a controlled trial and that seemed to be an unfortunate choice (Bach 2011; Sherry et al. 2011). The phase III trial using otelixizumab (Tolerx/GlaxoSmithKline trial) used a reduced dose with the aim to reduce side effects. This dose, which has not been validated for efficacy in a proper phase II placebocontrolled study, was more than 15 times less than the one used in the successful phase II trial (3.1 mg compared with 48).

Negative results reported in press releases for both studies caused great discouragement in the diabetes community (http://www.macrogenics. com/press_releases-284.html; http://www.gsk. com/media/pressreleases/2011/2011_pressrelease_10039.htm). Importantly, a post hoc analysis of the data from the teplizumab study was performed using the conventional end points validated by all previous trials in the field, namely, C-peptide production and insulin needs, which evidenced a significant therapeutic effect (Sherry et al. 2011). A better response was observed in patients presenting the highest stimulated C-peptide at inclusion and in children. The response was dose dependent, i.e., only observed in patients receiving the higher dose tested of $17 \mathrm{mg}$ (cumulated, equivalent for a $70 \mathrm{~kg}$ individual).

\section{Autologous Bone Marrow Transplantation}

Because the pathogenesis of autoimmune diseases in general, including T1D, has genetic components that can be expressed in cells of the lymphoid lineage (i.e., the source of pathogenic lymphocytes) and in antigen-presenting cells (dendritic cells and macrophages), these diseases can be considered, rightly, as diseases of hematopoietic stem cells (Ikehara et al. 1990). This has justified applying, in patients with severe autoimmune diseases, hematopoietic stem cell transplantation preceded by conditioning based on high doses of immunosuppressive drugs (Marmont et al. 1997; Tyndall and Gratwohl 1997; Ikehara 1998). In support of this approach fortuitous clinical observations had shown remission of severe autoimmune disease after allogeneic bone marrow transplantation performed to treat hematologic malignancies, which occurred concomitantly (McAllister et al. 1997). Results from experimental models had also been very encouraging. 
Thus, high rates of remission of various autoimmune diseases have been observed following allogeneic bone marrow transplants. Excellent results have been reported in spontaneous autoimmune diseases such as diabetes mellitus in NOD mice or mice presenting spontaneous lupus-like syndrome (Yasumizu et al. 1987; Kushida et al. 2000). Among the mechanisms to explain these results one can evoke the deletion, or elimination by apoptosis, of a certain proportion of autoreactive $\mathrm{T}$ cells after the colonization of the primary lymphoid organs (thymus and bone marrow) by cells of the marrow graft (i.e., central chimerism). One also finds such chimerism in the periphery (coexistence of cells from the recipient and the donor). Despite its effectiveness, allogeneic bone marrow transplantation remains very difficult, not to say impossible, to apply in autoimmunity because of important and life-threatening side effects that are the occurrence of graft-versus-host disease (GvHD), and of overimmunosuppression owing to the myeloablative conditioning treatment.

Thus, considering the experimental results showing that autologous bone marrow transplantation or autologous hematopoietic stem cell mobilization could be as effective as allogeneic transplants (Karussis et al. 1992a,b, 1993), a growing interest focused on this strategy. At first glance these results may appear surprising and even paradoxical because autoimmunity being a disease of the stem cells, any replacement by autologous cells should inevitably lead to a recurrence of the disease and not to a cure. Thus, the initial objective of the clinical application of autologous stem cell transplant was not a cure of the autoimmune disease but simply to have the possibility of using, in the context of particularly severe and recalcitrant diseases, an aggressive immunosuppression regime whose side effects (especially myelotoxicity) would be overcome by the autologous stem cell transplant. The big surprise was that in many cases, the effect went far beyond that of mere immunosuppression, translating into a complete and lasting cure of severe cases of multiple sclerosis, scleroderma, juvenile rheumatoid arthritis, and systemic lupus erythematosus. The explanation of this effect depends in part on the assumption that the treatments used for stem cell mobilization modulate the functional capacity of the stem cells recovered; in particular, by promoting their ability to recruit Tregs, which can actively control pathogenic effectors. This has been shown in experimental models for GCSF that is very often used in clinical protocols before transplantation to induce mobilization, or after transplantation, to promote recovery (Hadaya et al. 2005; Kared et al. 2005, 2006, 2008).

Adopting this rationale, the group of Voltarelli et al. performed a prospective phase I/II study of 23 patients with recent-onset T1D (aged 13-31 yr) (Voltarelli et al. 2007; Couri et al. 2009). Hematopoietic stem cells were mobilized with cyclophosphamide $\left(2.0 \mathrm{~g} / \mathrm{m}^{2}\right)$ and GCSF (10 $\mu / \mathrm{kg}$ per day), collected from peripheral blood by leukapheresis and cryopreserved. The cells were injected intravenously after conditioning with cyclophosphamide (200 mg/kg) and rabbit antithymocyte globulin $(4.5 \mathrm{mg} / \mathrm{kg})$. During the $7-36$ months of follow-up, 20 patients were weaned from insulin treatment. Of these, 12 patients were insulin independent for 14-52 months showing stimulated C-peptide response levels were significantly increased as compared with pretreatment values, and levels of hemoglobin A1c maintained at less than 7\% (Voltarelli et al. 2007; Couri et al. 2009). Eventually, all these patients became insulin dependent again. In terms of side effects, two patients developed bilateral nosocomial pneumonia, three patients developed late endocrine dysfunction, and nine patients developed oligospermia. In conclusion, results showed that this strategy might afford disease remission with, in about $50 \%$ of the patients, insulin independency for 1-4 years. The problem is, however, that the type of conditioning regimen applied is quite heavy, similar to the one used in life-threatening autoimmune diseases. When considering the risk/benefit ratio, it is difficult to justify this approach for wide application in T1D even if restricting the therapy to adolescents and adults. For obvious reasons, the strategy appears totally inappropriate for use in children. 
L. Chatenoud et al.

\section{Antigen-Specific Immunomodulation}

Antigen-based therapies aim to induce tolerance/protective immunity by targeting the regulatory immune responses to the site of T-cellmediated destruction or by eliminating antigenreactive clones. In animal models, it has been shown that administration of autoantigen or antigen peptides is effective in inducing regulatory immune responses that can prevent autoimmune diabetes. In particular, autoantigen administration modifies the cytokine-producing ability of pathogenic $\mathrm{T}$ cells; these normally are interferon (IFN) $\gamma$ producers and following treatment convert to nonpathogenic IL-4 producers (Tian et al. 1996; Elias et al. 1997; Tisch et al. 1999; Ludvigsson et al. 2008). If successful, antigen-based therapies are expected to have advantages with respect to fewer side effects as compared with broader immune-modulation or suppression strategies. Antigen-based therapies are therefore repeatedly tested in T1D prevention or reversal. However, thus far, their success has been limited and inconsistent. Prevention studies were conducted in genetically at-risk islet-autoantibody-positive subjects. Three large and one smaller trial were performed in this group of subjects: three showed no benefit from treatment with parenteral (DPT-1) (Diabetes Prevention Trial-Type 1 Diabetes Study Group 2002) or nasal insulin (which are the DIPP trial and the one conducted by the group of L. Harrison) (Nanto-Salonen et al. 2008; Fourlanos et al. 2011); the fourth showed no benefit from treatment with oral insulin in the study group (DPT-1) (Diabetes Prevention TrialType 1 Diabetes Study Group 2002) as a whole. However, some encouraging effects were seen after post hoc stratification of subjects: patients presenting high titers of anti-insulin antibodies did show a significant delay to diabetes onset. Two multicenter trials for secondary prevention are still ongoing, one using nasal insulin at markedly higher concentrations than the DIPP study (INITII) and one using oral insulin (TrialNet). An alternative is to intervene before the appearance of autoimmunity, and this is currently tested in a pilot dose-finding study using oral insulin vaccination in children with very high familial and genetic risk (Pre-POINT) (Achenbach 2008; www.diabetes-point.org). After clinical disease it is likely that antigen-based therapies alone may be insufficient to halt $\beta$-cell destruction, but may be valuable components of combination therapies.

\section{Insulin}

Insulin is among the first autoantigens in which autoantibodies are found in children who develop T1D. Therefore, insulin represents an obvious target for antigen-specific intervention. NBI-6024 is an altered-peptide ligand (APL) and contains two natural L-amino acid substitutions in the (9-23) sequence of the B chain of insulin. Alanine is substituted for tyrosine at position 16, which is a key contact site at the T-cell receptor and at position 19 for cysteine. The resulting APL (Ala16,19) does not activate insulin B (9-23)-reactive murine or human $\mathrm{T}$ cells. Nonobese diabetic mice treated with NBI-6024 were protected from developing diabetes, even though other $\mathrm{T}$ cells with different antigenic specificities were present (Alleva et al. 2002). In a recently published study, a total of 188 patients, aged $10-35 \mathrm{yr}$, with new-onset T1D were randomly assigned to a treatment consisting of the subcutaneous administration of placebo or $1,0.5$, or $0.1 \mathrm{mg}$ NBI-6024 every month for 2 years. The mean peak C-peptide concentrations at 24 months after study entry showed no difference between placebo and the various treatment groups. Fasting, stimulated peak, and AUC Cpeptide concentrations declined linearly in all groups by $60 \%$ over the 24 -month treatment period. The average daily insulin needs at month 24 were also comparable. No treatment-related changes in islet antibodies and T-cell numbers were observed. In conclusion, treatment with altered-peptide ligand NBI-6024 at repeated doses did not improve or maintain $\beta$-cell function (Walter et al. 2009).

Another therapeutic approach is the administration of short insulin peptides representing T-cell epitopes targeted by patients with T1D. In 2008, safety and mechanistic outcome of intradermal administration of a HLA-DR4-restricted peptide epitope of proinsulin (C19-A3) 
was investigated. The selected peptide is an epitope from the C-A chain junction present in proinsulin but not in insulin. It is a prominent target of CD4-T-cell responses. In the study, patients with long-standing T1D and HLADRB1*0401 genotype received $30 \mu \mathrm{g}(n=18)$ or $300 \mu \mathrm{g}(n=18)$ of peptide in equal doses at 0 , 1 , and 2 months or no intervention $(n=12)$. Proinsulin peptide immunotherapy was well tolerated and free from risk of systemic hypersensitivity and systemic hypersensitivity and induction/reactivation of proinsulin-specific, proinflammatory T cells. Further studies in newonset patients will examine whether proinsulin peptide immunotherapy has beneficial effects on markers of T-cell autoimmunity and preservation of $\beta$-cell mass (Thrower et al. 2008).

\section{Glutamic Acid Decarboxylase}

One promising development in the field of antigen-based therapies was the combination of antigen with adjuvant for vaccination. Whole recombinant human GAD 65 molecule was suspended in alum and was able to induce a potent regulatory immune response in NOD mice with established autoimmunity and after T1D onset (Tian et al. 1996; Tisch et al. 1999). An early dosefinding study in LADA patients revealed a possible effect on regulatory $\mathrm{CD} 4{ }^{+} \mathrm{CD} 25^{+} \mathrm{T}$ cells and suggested $\beta$-cell preservation (Agardh et al. 2005). The phase II trial in children and adolescents with recent-onset diabetes showed significant improvement of fasting C-peptide after 30 months (Ludvigsson et al. 2008). Recently, results of additional phase II and phase III studies were published (Wherrett et al. 2011; Ludvigsson et al. 2012). Unfortunately, no significant effect on $\beta$-cell function after 15 months of follow-up was observed in patients with new-onset T1D, aged 10-20 yr, although a small positive effect was seen. GAD-alum was well tolerated, as shown by a similar number of adverse events across treatment groups.

\section{Heat Shock Protein 60}

The Diapep 277 peptide of heat shock protein 60 (HSP 60) has been reported to preserve C-peptide in a small trial of LADA patients with a relatively short follow-up (Raz et al. 2001); phase II trials in children showed no or little effect (Lazar et al. 2007; Schloot et al. 2007). Two large phase III trials are currently ongoing in Europe and South Africa, enrolling patients between 16 and 45 years of age.

\section{CONCLUDING REMARKS AND PERSPECTIVES}

Although a large catalog of studies has been described, it is important to be reasonably comprehensive in the presentation of different immunointervention strategies that have been applied in clinical T1D. The catalog is representative of the scale of efforts that have been made using innovative avenues of approach based on experience in transplantation and the knowledge gained from animal models. Although these strategies have not yet resulted in consistent positive clinical application, we can, after nearly 30 years of hard work, reflect and draw specific conclusions for improving the implementation of future clinical trials, which one hopes will lead to the marketing of efficacious products.

The first question is can we go further on the path of nonspecific immunosuppression to identify a treatment that is potent enough to stop the progression of T1D without exposing one to an unacceptable risk of infections and tumors? It may be possible, although difficult. As we discussed, cyclosporin was not the way. Monoclonal antibody to CD20, which induced a significant therapeutic effect, did not induce tolerance and can therefore be considered as an immunosuppressant. Concerning CTLA4-Ig, it is too early to conclude, as data on the effect after treatment cessation are being collected. For such therapies, we need to ask ourselves whether short-term benefit is sufficient. The risks imposed by immunosuppression may be reduced by using treatments limited in time, aiming at delaying by 1 or 2 years the loss of $\beta$-cell function or the start of insulin therapy, but we suspect that the clinical and patient community wants more than this. We expect that distinction between immunosuppression versus tolerance is thus a primary criterion underlying 


\section{Chatenoud et al.}

the evaluation of any form of immune therapy in type 1 diabetes.

Presently, CD3 antibodies still appear a strong and advanced first step toward inducing a long-term tolerogenic effect following a short treatment. It is, however, important to critically readdress the recent phase III trials, for example, in the analysis of data and to learn from them so that patient selection, dosing, and timing of intervention is optimized. In parallel, efforts must be devoted to test and implement combination strategies whereby the efficacy of CD3 antibody treatment was enhanced in experimental models (i.e., anti-inflammatory agents, agents favoring $\beta$-cell regeneration, and autoantigens). In this endeavor one could benefit from recently described experimental models such as mice transgenic for the human $\varepsilon$ chain of $\mathrm{CD} 3$ that allow one to use the very same CD3 antibodies used in the clinic (Kuhn et al. 2011).

A second important practical question is how in future trials we may best probe not only efficacy but overall benefit. Life quality will be determined by the capacity of the potential candidate to prevent long-term degenerative complications, but this would imply conducting trials with a very prolonged follow-up $(>10 \mathrm{yr})$ that, for obvious reasons, is impractical. Although C-peptide preservation is a solid reflection of efficacy, one may question the validity of this parameter as a surrogate for long-term benefit. This is well illustrated by results showing that $\mathrm{C}$-peptide preservation does not always correlate with a significant decrease in insulin needs. It is clear that any short-term success in preserving C-peptide needs to be followed with discussions among academics, industry, and regulatory authorities to define additional end points for trials that will better reflect long-term life quality.

A third major issue is, of course, to address combination strategies. As for all complex diseases in T1D, it is obvious that only by combining agents, one may take advantage of synergies in the mode of action, reduce the dosages of single drugs, thereby decreasing side effects.

Today, immunotherapy of T1D has reached an exciting, yet challenging crossroad. Indeed, last year has been an especially rich one as it has seen the completion of many large clinical trials using a variety of therapeutic strategies. Some of the data were disappointing and others hold promise. The challenge is to keep the active involvement of academics, companies, and funding bodies in the field to meet the expectations of the patients and the whole diabetes community, thereby reinforcing the credibility on what we feel is the only solution to finding a real cure for T1D.

\section{REFERENCES}

Achenbach P, Barker J, Bonifacio E, Pre Point Study Group. 2008. Modulating the natural history of type 1 diabetes in children at high genetic risk by mucosal insulin immunization. Curr Diab Rep 8: 87-93.

Agardh CD, Cilio CM, Lethagen A, Lynch K, Leslie RD, Palmer M, Harris RA, Robertson JA, Lernmark A. 2005. Clinical evidence for the safety of GAD65 immunomodulation in adult-onset autoimmune diabetes. J Diabetes Complications 19: 238-246.

Alleva DG, Gaur A, Jin L, Wegmann D, Gottlieb PA, Pahuja A, Johnson EB, Motheral T, Putnam A, Crowe PD, et al. 2002. Immunological characterization and therapeutic activity of an altered-peptide ligand, NBI-6024, based on the immunodominant type 1 diabetes autoantigen insulin B-chain (9-23) peptide. Diabetes 51: 2126-2134.

Assan R, Feutren G, Debray-Sachs M, Quiniou-Debrie MC, Laborie C, Thomas G, Chatenoud L, Bach JF. 1985. Metabolic and immunological effects of cyclosporin in recently diagnosed type 1 diabetes mellitus. Lancet 1: 67-71.

Bach JF. 2011. Anti-CD3 antibodies for type 1 diabetes: Beyond expectations. Lancet 378: 459-460.

Bach JF, Chatenoud L. 2011. A historical view from thirty eventful years of immunotherapy in autoimmune diabetes. Semin Immunol 23: 174-181.

Baumgartl HJ, Standl E, Schmidt-Gayk H, Kolb HJ, Janka HU, Ziegler AG. 1991. Changes of vitamin D3 serum concentrations at the onset of immune-mediated type 1 (insulin-dependent) diabetes mellitus. Diabetes Res 16: 145-148.

Belghith M, Bluestone JA, Barriot S, Megret J, Bach JF, Chatenoud L. 2003. TGF- $\beta$-dependent mechanisms mediate restoration of self-tolerance induced by antibodies to CD3 in overt autoimmune diabetes. Nat Med 9: 12021208.

Bierschenk L, Alexander J, Wasserfall C, Haller M, Schatz D, Atkinson M. 2009. Vitamin D levels in subjects with and without type 1 diabetes residing in a solar rich environment. Diabetes Care 32: 1977-1979.

Billingham RE, Brent L, Medawar PB. 1953. Actively acquired tolerance to foreign cells. Nature 172: 603-606.

Bluestone JA, St Clair EW, Turka LA. 2006. CTLA4Ig: Bridging the basic immunology with clinical application. Immunity 24: 233-238. 
Brazelton TR, Morris RE. 1996. Molecular mechanisms of action of new xenobiotic immunosuppressive drugs: Tacrolimus (FK506), sirolimus (rapamycin), mycophenolate mofetil and leflunomide. Curr Opin Immunol 8: $710-720$.

Chatenoud L. 2003. CD3-specific antibody-induced active tolerance: From bench to bedside. Nat Rev Immunol 3: $123-132$.

Chatenoud L. 2010. Immune therapy for type 1 diabetes mellitus-What is unique about anti-CD3 antibodies? Nat Rev Endocrinol 6: 149-157.

Chatenoud L, Bluestone JA. 2007. CD3-specific antibodies: A portal to the treatment of autoimmunity. Nat Rev Immunol 7: 622-632.

Chatenoud L, Thervet E, Primo J, Bach JF. 1994. Anti-CD3 antibody induces long-term remission of overt autoimmunity in nonobese diabetic mice. Proc Natl Acad Sci 91: $123-127$.

Chatenoud L, Primo J, Bach JF. 1997. CD3 antibody-induced dominant self tolerance in overtly diabetic NOD mice. J Immunol 158: 2947-2954.

Couri CE, Oliveira MC, Stracieri AB, Moraes DA, Pieroni F, Barros GM, Madeira MI, Malmegrim KC, Foss-Freitas MC, Simoes BP, et al. 2009. C-peptide levels and insulin independence following autologous nonmyeloablative hematopoietic stem cell transplantation in newly diagnosed type 1 diabetes mellitus. JAMA 301: 1573-1579.

Diabetes Prevention Trial-Type 1 Diabetes Study Group. 2002. Effects of insulin in relatives of patients with type 1 diabetes mellitus. $N$ Engl J Med 346: 1685-1691.

Eisenbarth GS, Srikanta S, Jackson R, Rabinowe S, Dolinar R, Aoki T, Morris MA. 1985. Anti-thymocyte globulin and prednisone immunotherapy of recent onset type 1 diabetes mellitus. Diabetes Res 2: 271-276.

Eizirik DL, Colli ML, Ortis F. 2009. The role of inflammation in insulitis and $\beta$-cell loss in type 1 diabetes. Nat Rev Endocrinol 5: 219-226.

Elias D, Meilin A, Ablamunits V, Birk OS, Carmi P, Konenwaisman S, Cohen IR. 1997. Hsp60 peptide therapy of NOD mouse diabetes induces a Th2 cytokine burst and downregulates autoimmunity to various $\beta$-cell antigens. Diabetes 46: 758-764.

Feldmann M. 2002. Development of anti-TNF therapy for rheumatoid arthritis. Nat Rev Immunol 2: 364-371.

Feutren G, Papoz L, Assan R, Vialettes B, Karsenty G, Vexiau P, Du Rostu H, Rodier M, Sirmai J, Lallemand A, et al. 1986. Cyclosporin increases the rate and length of remissions in insulin-dependent diabetes of recent onset. Results of a multicentre double-blind trial. Lancet 2: 119124.

Fourlanos S, Perry C, Gellert SA, Martinuzzi E, Mallone R, Butler J, Colman PG, Harrison LC. 2011. Evidence that nasal insulin induces immune tolerance to insulin in adults with autoimmune diabetes. Diabetes 60: 1237 1245 .

Füchtenbusch M, Kredel K, Bonifacio E, Schnell O, Ziegler AG. 2000. Exposure to exogenous insulin promotes IgG1 and the T-helper 2-associated IgG4 responses to insulin but not to other islet autoantigens. Diabetes 49: 918-925.

Gottlieb PA, Quinlan S, Krause-Steinrauf H, Greenbaum CJ, Wilson DM, Rodriguez H, Schatz DA, Moran AM, Lachin
Clinical Interventions for the Treatment of T1D

JM, Skyler JS. 2010. Type 1 Diabetes TrialNet MMF/DZB Study Group. Failure to preserve $\beta$-cell function with mycophenolate mofetil and daclizumab combined therapy in patients with new-onset type 1 diabetes. Diabetes Care 33: 826-832.

Gysemans CA, Cardozo AK, Callewaert H, Giulietti A, Hulshagen L, Bouillon R, Eizirik DL, Mathieu C. 2005. 1,25Dihydroxyvitamin D3 modulates expression of chemokines and cytokines in pancreatic islets: Implications for prevention of diabetes in nonobese diabetic mice. Endocrinology 146: 1956-1964.

Hadaya K, Kared H, Masson A, Chatenoud L, Zavala F. 2005. G-CSF treatment prevents cyclophosphamide acceleration of autoimmune diabetes in the NOD mouse. J Autoimmun 24: 125-134.

Hannum CH, Wilcox CJ, Arend WP, Joslin FG, Dripps DJ, Heimdal PL, Armes LG, Sommer A, Eisenberg SP, Thompson RC. 1990. Interleukin-1 receptor antagonist activity of a human interleukin-1 inhibitor. Nature 343: 336-340.

Herold KC, Hagopian W, Auger JA, Poumian Ruiz E, Taylor L, Donaldson D, Gitelman SE, Harlan DM, Xu D, Zivin RA, et al. 2002. Anti-CD3 monoclonal antibody in newonset type 1 diabetes mellitus. N Engl J Med 346: $1692-$ 1698.

Herold KC, Gitelman SE, Masharani U, Hagopian W, Bisikirska B, Donaldson D, Rother K, Diamond B, Harlan DM, Bluestone JA. 2005. A single course of anti-CD3 monoclonal antibody hOKT3yl(Ala-Ala) results in improvement in C-peptide responses and clinical parameters for at least 2 years after onset of type 1 diabetes. Diabetes 54: 1763-1769.

Hirsch R, Bluestone JA, De Nenno L, Gress RE. 1990. Anti$\mathrm{CD} 3 \mathrm{~F}\left(\mathrm{ab}^{\prime}\right) 2$ fragments are immunosuppressive in vivo without evoking either the strong humoral response or morbidity associated with whole $\mathrm{mAb}$. Transplantation 49: 1117-1123.

Hu CY, Rodriguez-Pinto D, Du W, Ahuja A, Henegariu O, Wong FS, Shlomchik MJ, Wen L. 2007. Treatment with CD20-specific antibody prevents and reverses autoimmune diabetes in mice. J Clin Invest 117: 3857-3867.

Hypponen E, Laara E, Reunanen A, Jarvelin MR, Virtanen SM. 2001. Intake of vitamin D and risk of type 1 diabetes: A birth-cohort study. Lancet 358: 1500-1503.

Ikehara S. 1998. Bone marrow transplantation for autoimmune diseases. Acta Haematol 99: 116-132.

Ikehara S, Kawamura M, Takao F, Inaba M, Yasumizu R, Than S, Hisha H, Sugiura K, Koide Y, Yoshida TO, et al. 1990. Organ-specific and systemic autoimmune diseases originate from defects in hematopoietic stem cells. Proc Natl Acad Sci 87: 8341-8344.

Kared H, Masson A, Adle-Biassette H, Bach JF, Chatenoud L, Zavala F. 2005. Treatment with granulocyte colony-stimulating factor prevents diabetes in NOD mice by recruiting plasmacytoid dendritic cells and functional $\mathrm{CD} 4^{+}$ $\mathrm{CD} 25^{+}$regulatory T-cells. Diabetes 54: 78-84.

Kared H, Adle-Biassette H, Fois E, Masson A, Bach JF, Chatenoud L, Schneider E, Zavala F. 2006. Jagged2-expressing hematopoietic progenitors promote regulatory $\mathrm{T}$ cell expansion in the periphery through notch signaling. Immunity 25: 823-834. 
L. Chatenoud et al.

Kared H, Leforban B, Montandon R, Renand A, Layseca Espinosa E, Chatenoud L, Rosenstein Y, Schneider E, Dy M, Zavala F. 2008. Role of GM-CSF in tolerance induction by mobilized hematopoietic progenitors. Blood 112: $2575-2578$.

Karussis DM, Slavin S, Ben-nun A, Ovadia H, Vourka-karussis U, Lehmann D, Mizrachi-kol R, Abramsky O. 1992a. Chronic-relapsing experimental autoimmune encephalomyelitis (CR-EAE): Treatment and induction of tolerance, with high dose cyclophosphamide followed by syngeneic bone marrow transplantation. JNeuroimmunol 39: $201-210$.

Karussis DM, Slavin S, Lehmann D, Mizrachi-koll R, Abramsky O, Ben-nun A. 1992b. Prevention of experimental autoimmune encephalomyelitis and induction of tolerance with acute immunosuppression followed by syngeneic bone marrow transplantation. J Immunol 148: $1693-1698$.

Karussis DM, Vourka-karussis U, Lehmann D, Ovadia H, Mizrachi-koll R, Ben-nun A, Abramsky O, Slavin S. 1993. Prevention and reversal of adoptively transferred, chronic relapsing experimental autoimmune encephalomyelitis with a single high dose cytoreductive treatment followed by syngeneic bone marrow transplantation. J Clin Invest 92: 765-772.

Keymeulen B, Vandemeulebroucke E, Ziegler AG, Mathieu C, Kaufman L, Hale G, Gorus F, Goldman M, Walter M, Candon S, et al. 2005. Insulin needs after CD3-antibody therapy in new-onset type 1 diabetes. $N$ Engl J Med 352: 2598-2608.

Keymeulen B, Walter M, Mathieu C, Kaufman L, Gorus F, Hilbrands R, Vandemeulebroucke E, Van de Velde U, Crenier L, De Block C, et al. 2010. Four-year metabolic outcome of a randomised controlled CD3-antibody trial in recent-onset type 1 diabetic patients depends on their age and baseline residual $\beta$ cell mass. Diabetologia 53: 614-623.

Kohm AP, Williams JS, Bickford AL, McMahon JS, Chatenoud L, Bach JF, Bluestone JA, Miller SD. 2005. Treatment with nonmitogenic anti-CD3 monoclonal antibody induces $\mathrm{CD}^{+} \mathrm{T}$ cell unresponsiveness and functional reversal of established experimental autoimmune encephalomyelitis. J Immunol 174: 4525-4534.

Kremer JM, Westhovens R, Leon M, Di Giorgio E, Alten R, Steinfeld S, Russell A, Dougados M, Emery P, Nuamah IF, et al. 2003. Treatment of rheumatoid arthritis by selective inhibition of T-cell activation with fusion protein CTLA4Ig. N Engl J Med 349: 1907-1915.

Kuhn C, You S, Valette F, Hale G, van Endert P, Bach JF, Waldmann H, Chatenoud L. 2011. Human CD3 transgenic mice: Preclinical testing of antibodies promoting immune tolerance. Sci Transl Med 3: 68ra10.

Kushida T, Inaba M, Takeuchi K, Sugiura K, Ogawa R, Ikehara S. 2000. Treatment of intractable autoimmune diseases in MRL/lpr mice using a new strategy for allogeneic bone marrow transplantation. Blood 95: 1862-1868.

Larsen CM, Faulenbach M, Vaag A, Volund A, Ehses JA, Seifert B, Mandrup-Poulsen T, Donath MY. 2007. Interleukin-1-receptor antagonist in type 2 diabetes mellitus. N Engl J Med 356: 1517-1526.

Lazar L, Ofan R, Weintrob N, Avron A, Tamir M, Elias D, Phillip M, Josefsberg Z. 2007. Heat-shock protein pep- tide DiaPep277 treatment in children with newly diagnosed type 1 diabetes: A randomised, double-blind phase II study. Diabetes Metab Res Rev 23: 286-291.

Like AA, Rossini AA, Guberski DL, Appel MC, Williams RM. 1979. Spontaneous diabetes mellitus: Reversal and prevention in the $\mathrm{BB} / \mathrm{W}$ rat with antiserum to rat lymphocytes. Science 206: 1421-1423.

Ludvigsson J, Faresjo M, Hjorth M, Axelsson S, Cheramy M, Pihl M, Vaarala O, Forsander G, Ivarsson S, Johansson C, et al. 2008. GAD treatment and insulin secretion in recent-onset type 1 diabetes. N Engl J Med 359: 1909-1920.

Ludvigsson J, Krisky D, Casas R, Battelino T, Castano L, Greening J, Kordonouri O, Otonkoski T, Pozzilli P, Robert JJ. 2012. GAD65 antigen therapy in recently diagnosed type 1 diabetes mellitus. $N$ Engl J Med 366: 433-442.

Makhlouf L, Grey ST, Dong V, Csizmadia E, Arvelo MB, Auchincloss H Jr, Ferran C, Sayegh MH. 2004. Depleting anti-CD4 monoclonal antibody cures new-onset diabetes, prevents recurrent autoimmune diabetes, and delays allograft rejection in nonobese diabetic mice. Transplantation 77: 990-997.

Maki T, Ichikawa T, Blanco R, Porter J. 1992. Long-term abrogation of autoimmune diabetes in nonobese diabetic mice by immunotherapy with anti-lymphocyte serum. Proc Natl Acad Sci 89: 3434-3438.

Mandrup-Poulsen T. 1996. The role of interleukin-1 in the pathogenesis of IDDM. Diabetologia 39: 1005-1029.

Mandrup-Poulsen T, Pickersgill L, Donath MY. 2010. Blockade of interleukin 1 in type 1 diabetes mellitus. Nat Rev Endocrinol 6: 158-166.

Marmont AM, Van Lint MT, Gualandi F, Bacigalupo A. 1997. Autologous marrow stem cell transplantation for severe systemic lupus erythematosus of long duration. Lupus 6: 545-548.

Martin S, Schernthaner G, Nerup J, Gries FA, Koivisto VA, Dupré J, Standl E, Hamet P, McArthur R, Tan MH, et al. 1991. Follow-up of cyclosporin A treatment in type 1 (insulin-dependent) diabetes mellitus: Lack of longterm effects. Diabetologia 34: 429-434.

Mastrandrea L, Yu J, Behrens T, Buchlis J, Albini C, Fourtner S, Quattrin T. 2009. Etanercept treatment in children with new-onset type 1 diabetes: Pilot randomized, placebocontrolled, double-blind study. Diabetes Care 32: 12441249.

Mathieu C, Gysemans C, Giulietti A, Bouillon R. 2005. Vitamin D and diabetes. Diabetologia 48: 1247-1257.

McAllister LD, Beatty PG, Rose J. 1997. Allogeneic bone marrow transplant for chronic myelogenous leukemia in a patient with multiple sclerosis. Bone Marrow Transplant 19: 395-397.

Monaco AP, Wood ML, Russell PS. 1966. Studies on heterologous antilymphocyte serum in mice. III. Immunological tolerance and chimerism produced across the $\mathrm{H} 2$ locus with adult thymectomy and antilymphocyte serum. Ann NY Acad Sci 129: 190-209.

Nanto-Salonen K, Kupila A, Simell S, Siljander H, Salonsaari T, Hekkala A, Korhonen S, Erkkola R, Sipila JI, Haavisto L, et al. 2008. Nasal insulin to prevent type 1 diabetes in children with HLA genotypes and autoantibodies conferring increased risk of disease: A doubleblind, randomised controlled trial. Lancet 372: 17461755. 
Ogilvie AL, Antoni C, Dechant C, Manger B, Kalden JR, Schuler G, Luftl M. 2001. Treatment of psoriatic arthritis with antitumour necrosis factor- $\alpha$ antibody clears skin lesions of psoriasis resistant to treatment with methotrexate. Br J Dermatol 144: 587-589.

Orban T, Bundy B, Becker DJ, Dimeglio LA, Gitelman SE, Goland R, Gottlieb PA, Greenbaum CJ, Marks JB, Monzavi R, et al. 2011. Co-stimulation modulation with abatacept in patients with recent-onset type 1 diabetes: A randomised, double-blind, placebo-controlled trial. Lancet 378: 412-419.

Patterson CC, Dahlquist GG, Gyurus E, Green A, Soltesz G. 2009. Incidence trends for childhood type 1 diabetes in Europe during 1989-2003 and predicted new cases 2005-20: A multicentre prospective registration study. Lancet 373: 2027-2033.

Penaranda C, Tang Q, Bluestone JA. 2011. Anti-CD3 therapy promotes tolerance by selectively depleting pathogenic cells while preserving regulatory T cells. J Immunol 187: 2015-2022.

Penna G, Amuchastegui S, Giarratana N, Daniel KC, Vulcano M, Sozzani S, Adorini L. 2007a. 1,25-Dihydroxyvitamin D3 selectively modulates tolerogenic properties in myeloid but not plasmacytoid dendritic cells. J Immunol 178: $145-153$.

Penna G, Amuchastegui S, Laverny G, Adorini L. 2007b. Vitamin D receptor agonists in the treatment of autoimmune diseases: Selective targeting of myeloid but not plasmacytoid dendritic cells. J Bone Miner Res 22: V69_ V73.

Pescovitz MD, Greenbaum CJ, Krause-Steinrauf H, Becker DJ, Gitelman SE, Goland R, Gottlieb PA, Marks JB, McGee PF, Moran AM, et al. 2009. Rituximab, B-lymphocyte depletion, and preservation of $\beta$-cell function. $N$ Engl J Med 361: 2143-2152.

Pitocco D, Crino A, Di Stasio E, Manfrini S, Guglielmi C, Spera S, Anguissola GB, Visalli N, Suraci C, Matteoli MC, et al. 2006. The effects of calcitriol and nicotinamide on residual pancreatic $\beta$-cell function in patients with recent-onset type 1 diabetes (IMDIAB XI). Diabet Med 23: 920-923.

Raz I, Elias D, Avron A, Tamir M, Metzger M, Cohen IR. 2001. $\beta$-cell function in new-onset type 1 diabetes and immunomodulation with a heat-shock protein peptide (DiaPep277): A randomised, double-blind, phase II trial. Lancet 358: 1749-1753.

Reff ME, Carner K, Chambers KS, Chinn PC, Leonard JE, Raab R, Newman RA, Hanna N, Anderson DR. 1994. Depletion of $\mathrm{B}$ cells in vivo by a chimeric mouse human monoclonal antibody to CD20. Blood 83: 435-445.

Sakaguchi S, Ono M, Setoguchi R, Yagi H, Hori S, Fehervari Z, Shimizu J, Takahashi T, Nomura T. 2006. Foxp $3^{+}$ $\mathrm{CD}_{2} 5^{+} \mathrm{CD} 4^{+}$natural regulatory $\mathrm{T}$ cells in dominant self-tolerance and autoimmune disease. Immunol Rev 212: $8-27$.

Salomon B, Lenschow DJ, Rhee L, Ashourian N, Singh B, Sharpe A, Bluestone JA. 2000. B7/CD28 Costimulation is essential for the homeostasis of the $\mathrm{CD} 4{ }^{+} \mathrm{CD} 25^{+}$immunoregulatory $\mathrm{T}$ cells that control autoimmune diabetes. Immunity 12: 431-440.

Saudek F, Havrdova T, Boucek P, Karasova L, Novota P, Skibova J. 2004. Polyclonal anti-T-cell therapy for type 1 diabetes mellitus of recent onset. Rev Diabet Stud 1: $80-88$.

Schloot NC, Meierhoff G, Lengyel C, Vandorfi G, Takacs J, Panczel P, Barkai L, Madacsy L, Oroszlan T, Kovacs P, et al. 2007. Effect of heat shock protein peptide DiaPep277 on $\beta$-cell function in paediatric and adult patients with recent-onset diabetes mellitus type 1: Two prospective, randomized, double-blind phase II trials. Diabetes Metab Res Rev 23: 276-285.

Serreze DV, Chapman HD, Varnum DS, Hanson MS, Reifsnyder PC, Richard SD, Fleming SA, Leiter EH, Shultz LD. 1996. B lymphocytes are essential for the initiation of T cell-mediated autoimmune diabetes: Analysis of a new "speed congenic" stock of NOD.Ig mu(null) mice. J Exp Med 184: 2049-2053.

Sherry N, Hagopian W, Ludvigsson J, Jain SM, Wahlen J, Ferry RJ Jr, Bode B, Aronoff S, Holland C, Carlin C, et al. 2011. Teplizumab for treatment of type 1 diabetes (Protege study): 1-year results from a randomised, placebocontrolled trial. Lancet 378: 487-497.

Sigal NH, Dumont FJ. 1992. Cyclosporin A, FK-506, and rapamycin: Pharmacologic probes of lymphocyte signal transduction. Annu Rev Immunol 10: 519-560.

Simon G, Parker M, Ramiya V, Wasserfall C, Huang Y, Bresson D, Schwartz RF, Campbell-Thompson M, Tenace L, Brusko T, et al. 2008. Murine antithymocyte globulin therapy alters disease progression in NOD mice by a time-dependent induction of immunoregulation. Diabetes 57: 405-414.

Sreenan S, Pick AJ, Levisetti M, Baldwin AC, Pugh W, Polonsky KS. 1999. Increased $\beta$-cell proliferation and reduced mass before diabetes onset in the nonobese diabetic mouse. Diabetes 48: 989-996.

Stiller CR, Dupre J, Gent M, Jenner MA, Keown PA, Laupacis A, Martell R, Rodger NW, Von Graffenried B, Wolfe BM. 1984. Effects of cyclosporine immunosuppression in insulin-dependent diabetes mellitus of recent onset. Science 223: 1362-1367.

Tang Q, Henriksen KJ, Boden EK, Tooley AJ, Ye J, Subudhi SK, Zheng XX, Strom TB, Bluestone JA. 2003. Cutting edge: CD28 controls peripheral homeostasis of $\mathrm{CD}^{+}$ $\mathrm{CD}^{+} 5^{+}$regulatory T cells. J Immunol 171: 3348-3352.

The Canadian-European Randomized Control Trial Group. 1988. Cyclosporin-induced remission of IDDM after early intervention. Association of $1 \mathrm{yr}$ of cyclosporin treatment with enhanced insulin secretion. Diabetes 37: 1574-1582.

Thrower SL, James L, Hall W, Green KM, Arif S, Allen JS, Van Krinks C, Lozanoska-Ochser B, Marchesini L, Brown S, et al. 2009. Proinsulin peptide immunotherapy in type 1 diabetes: Report of a first-in-man Phase I safety study. Clin Exp Immunol 155: 156-165.

Tian J, Atkinson MA, Clare Salzler M, Herschenfeld A, Forsthuber T, Lehmann PV, Kaufman DL. 1996. Nasal administration of glutamate decarboxylase (GAD65) peptides induces Th2 responses and prevents murine insulin-dependent diabetes. J Exp Med 183: 1561-1567.

Tisch R, Wang B, Serreze DV. 1999. Induction of glutamic acid decarboxylase 65 -specific Th2 cells and suppression of autoimmune diabetes at late stages of disease is epitope dependent. J Immunol 163: 1178-1187. 


\section{Chatenoud et al.}

Tyndall A, Gratwohl A. 1997. Bone marrow transplantation in the treatment of autoimmune diseases. Br J Rheumatol 36: $1-3$.

Vincenti F, Kirkman R, Light S, Bumgardner G, Pescovitz M, Halloran P, Neylan J, Wilkinson A, Ekberg H, Gaston R, et al. 1998. Interleukin-2-receptor blockade with daclizumab to prevent acute rejection in renal transplantation. Daclizumab Triple Therapy Study Group. $N$ Engl J Med 338: $161-165$.

Vincenti F, Larsen C, Durrbach A, Wekerle T, Nashan B, Blancho G, Lang P, Grinyo J, Halloran PF, Solez K, et al. 2005. Costimulation blockade with belatacept in renal transplantation. N Engl J Med 353: 770-781.

VIT D Eurodiab. 1999. Vitamin D supplement in early childhood and risk for type I (insulin-dependent) diabetes mellitus. The EURODIAB Substudy 2 Study Group. Diabetologia 42: 51-54.

Voltarelli JC, Couri CE, Stracieri AB, Oliveira MC, Moraes DA, Pieroni F, Coutinho M, Malmegrim KC, Foss-Freitas MC, Simoes BP, et al. 2007. Autologous nonmyeloablative hematopoietic stem cell transplantation in newly diagnosed type 1 diabetes mellitus. JAMA 297: 1568-1576.

Walter M, Philotheou A, Bonnici F, Ziegler AG, Jimenez R. 2009. No effect of the altered-peptide ligand nbi-6024 on $\beta$ cell residual function and insulin needs in new-onset type 1 diabetes. Diabetes Care 32: 2036-2040.

Walter M, Kaupper T, Adler K, Foersch J, Bonifacio E, Ziegler AG. 2010. No effect of the 1 $\alpha, 25$-dihydroxyvitamin $\mathrm{D} 3$ on $\beta$-cell residual function and insulin requirement in adults with new-onset type 1 diabetes. Diabetes Care 33: $1443-1438$.

Wherrett DK, Bundy B, Becker DJ, Dimeglio LA, Gitelman SE, Goland R, Gottlieb AP, Greenbaum CJ, Herold KC,
Marks JB, et al. 2011. Antigen-based therapy with glutamic acid decarboxylase (GAD) vaccine in patients with recent-onset type 1 diabetes: A randomised double-blind trial. Lancet 378: 319-327.

Wojciechowski D, Vincenti F. 2011. Challenges and opportunities in targeting the costimulation pathway in solid organ transplantation. Semin Immunol 23: 157-164.

Wood ML, Monaco AP, Gozzo JJ, Liegeois A. 1971. Use of homozygous allogeneic bone marrow for induction of tolerance with antilymphocyte serum: Dose and timing. Transplant Proc 3: 676-679.

Yasumizu R, Sugiura K, Iwai H, Inaba M, Makino S, Ida T, Imura H, Hamashima Y, Good RA, Ikehara S. 1987. Treatment of type 1 diabetes mellitus in non-obese diabetic mice by transplantation of allogeneic bone marrow and pancreatic tissue. Proc Natl Acad Sci 84: 6555-6557.

You S, Thieblemont N, Alyanakian MA, Bach JF, Chatenoud L. 2006. Transforming growth factor- $\beta$ and T-cell-mediated immunoregulation in the control of autoimmune diabetes. Immunol Rev 212: 185-202.

You S, Leforban B, Garcia C, Bach JF, Bluestone JA, Chatenoud L. 2007. Adaptive TGF- $\beta$-dependent regulatory T cells control autoimmune diabetes and are a privileged target of anti-CD3 antibody treatment. Proc Natl Acad Sci 104: 6335-6340.

Young NS, Calado RT, Scheinberg P. 2006. Current concepts in the pathophysiology and treatment of aplastic anemia. Blood 108: 2509-2519.

Zipitis CS, Akobeng AK. 2008. Vitamin D supplementation in early childhood and risk of type 1 diabetes: A systematic review and meta-analysis. Arch Dis Child 93: 512 517. 


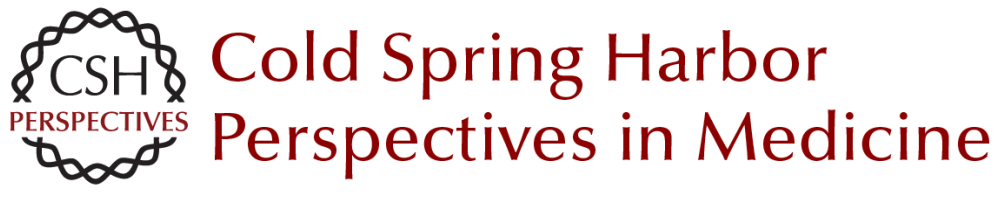

\title{
Clinical Immunologic Interventions for the Treatment of Type 1 Diabetes
}

\author{
Lucienne Chatenoud, Katharina Warncke and Anette-G. Ziegler
}

Cold Spring Harb Perspect Med 2012; doi: 10.1101/cshperspect.a007716 originally published online June 7, 2012

\section{Subject Collection Type I Diabetes}

The Pathogenesis and Natural History of Type 1

Diabetes

Mark A. Atkinson

Do MHCII-Presented Neoantigens Drive Type 1 Diabetes and Other Autoimmune Diseases? Philippa Marrack and John W. Kappler

Clinical Immunologic Interventions for the Treatment of Type 1 Diabetes Lucienne Chatenoud, Katharina Warncke and Anette-G. Ziegler

Update on Islet Transplantation Michael McCall and A.M. James Shapiro

Immunologic and Metabolic Biomarkers of $\beta$-Cell Destruction in the Diagnosis of Type 1 Diabetes Jasmin Lebastchi and Kevan C. Herold

Advancing Animal Models of Human Type 1 Diabetes by Engraftment of Functional Human

Tissues in Immunodeficient Mice Michael A. Brehm, Alvin C. Powers, Leonard D. Shultz, et al.

Breakdown in Peripheral Tolerance in Type 1 Diabetes in Mice and Humans Lukas T. Jeker, Hélène Bour-Jordan and Jeffrey $A$. Bluestone

Antigen-Specific Therapeutic Approaches in Type 1 Diabetes Xavier Clemente-Casares, Sue Tsai, Carol Huang, et al.
Humoral Autoimmunity in Type 1 Diabetes:

Prediction, Significance, and Detection of Distinct Disease Subtypes

Massimo Pietropaolo, Roberto Towns and George S. Eisenbarth

Endoplasmic Reticulum Stress, Pancreatic $\beta$-Cell Degeneration, and Diabetes Feroz R. Papa

Islet Autoantigens: Structure, Function, Localization, and Regulation Peter Arvan, Massimo Pietropaolo, David Ostrov, et al.

Environmental Triggers of Type 1 Diabetes Mikael Knip and Olli Simell

Generating $\beta$ Cells from Stem Cells--The Story So Far Matthias Hebrok

Antigen Targets of Type 1 Diabetes Autoimmunity Bart O. Roep and Mark Peakman

Connecting Type 1 and Type 2 Diabetes through Innate Immunity Justin I. Odegaard and Ajay Chawla

The Hygiene Hypothesis: An Explanation for the Increased Frequency of Insulin-Dependent Diabetes Jean-François Bach and Lucienne Chatenoud

For additional articles in this collection, see http://perspectivesinmedicine.cshlp.org/cgi/collection/ 